\title{
Notices of A Remarkable Collection of Ornaments of The Roman Period, Connected With The Worship of The Deæ Matres, and Recently Purchased for The British Museum
}

\section{Edward Hawkins}

To cite this article: Edward Hawkins (1851) Notices of A Remarkable Collection of Ornaments of The Roman Period, Connected With The Worship of The Deæ Matres, and Recently Purchased for The British Museum, Archaeological Journal, 8:1, 35-44, DOI: 10.1080/00665983.1851.10850811

To link to this article: http://dx.doi.org/10.1080/00665983.1851.10850811

曲 Published online: 10 Jul 2014.

Submit your article to this journal ¿

Џll Article views: 1

Q View related articles $\square$ 
knife and a key. A comb was found, formed of bone, and resembling those previously in Mr. Neville's collection, found at Chesterford. Three pins of bone, in a perfect state, and several broken pins. A profuse variety of examples of the bone acus, of all sizes and fashions, have been repeatedly found in the excavations directed by Mr. Neville.

Numerous fragments of Roman glass were produced. The remains of animals were met with, as usually the case in such excavations, in large quantities.

The coins discovered, about twenty in number, comprised a third brass of Gallienus (A.D. 253 to 268) Obv. a galeated head to the R.-GALLIENVS AVG. Rev. a centaur,-APPOLINI CONS. AVG. In the exergue, $\mathrm{z}$.

Third brass of Constantine the Great, struck at Treves. Rev. Two Victories holding a flag, inscribed-vот. P. R. Legend, VICTORIA LATIA . PRINC . PERP. In the exergue, S. T. R. Amongst the others, generally in bad condition, are coins of Victorinus, Allectus, Constantine, and Valentinian.

NOTICES OF A REMARKABLE COLLECTION OF ORNAMENTS OF THE ROMAN PERIOD, CONNECTED WITH THE WORSHIP OF THE DEA MATRES, AND RECENTLY PURCHASED FOR THE BRITISH MUSEUM.

THE objects to which the following observations relate compose a small collection of antiquities discovered, about the beginning of this century, in the county of Durham, or in some adjoining district. The exact locality was cautiously concealed, that they might not be claimed from the discoverer by the lord of the manor, or perhaps from the lord himself by the Lords of the Treasury, under the provisions of the law of treasure trove. ${ }^{1}$ They are said to have been hawked about privately, till they were ultimately purchased by a silversmith in Newcastle-upon-Tyne, who unfortunately parted with some portion of them before they were seen by Mr. Brumell, who immediately purchased all that remained in the silversmith's possession; and archaeologists are much indebted to that gentleman for keeping

${ }^{1}$ It is stated in Hodgson's Hist. of Northumberland, vol. iii., App., p. 440, that they were found somewhere in that county, N.E. of Backworth, and brought to Neweastle
in 1811 . 
them all together, and not allowing them to be separated when ill health induced him to discontinue collecting, and to sell, by public auction, the treasures, the collecting of which had long afforded him the highest gratification.

The find consisted of an elegant silver vessel resembling a saucepan, with the objects contained in it, and a small silver dish. In the vessel were found five gold rings; one silver ring; two gold chains, with ornaments attached to them ; a gold bracelet; a pair of large silver-gilt fibulæ; three silver spoons, two oval and one circular; about 280 Roman denarii ; and two large brass coins of Antoninus Pius. On the vessel was found a mirror, which was supposed, but erroneously, to be the lid or cover of the pot. Of all these objects, the saucepan, the six rings, the gold chains, the bracelet, the pair of fibulæ, the three spoons, the mirror, and one of the denarii, remained in the possession of Mr. Brumell, and were, at his sale, purchased for the British Museum. The dish had been disposed of before Mr. Brumell saw them.

The vessel, which resembles a modern saucepan, is of a form by no means uncommon amongst the remains of Roman metal antiquities. They are generally manufactured with great neatness, and sometimes in nests, fitting accurately one into another; their handles perforated, so that several may be hung upon one peg, occupying only a small space in the culinary territories, and peculiarly well adapted for a travelling or camp equipage. The bottoms are very neatly decorated with turned concentric circles, and being flat, are well calculated for heating anything upon the fire. The vessel now under consideration varies in some respects from this description. It is not so well fitted for placing upon the fire, as the bottom is raised by a rim about half an inch high, which might in some degree impede the effect of the fire upon anything cooked therein, and be itself exposed to injury by the fire. It would, however, protect the table from the heat of any hot mess served up in the vessel, and the handle would in some degree protect the fingers of the person carrying it. It might have served for the purpose of pouring out libations; but it is much deeper than the vessels for that purpose generally seen in sculptures, nor are such furnished with handles. Upon the whole, it may most safely be considered as a domestic utensil used in the establishment of the persons indicated by the inscription upon the handle. 


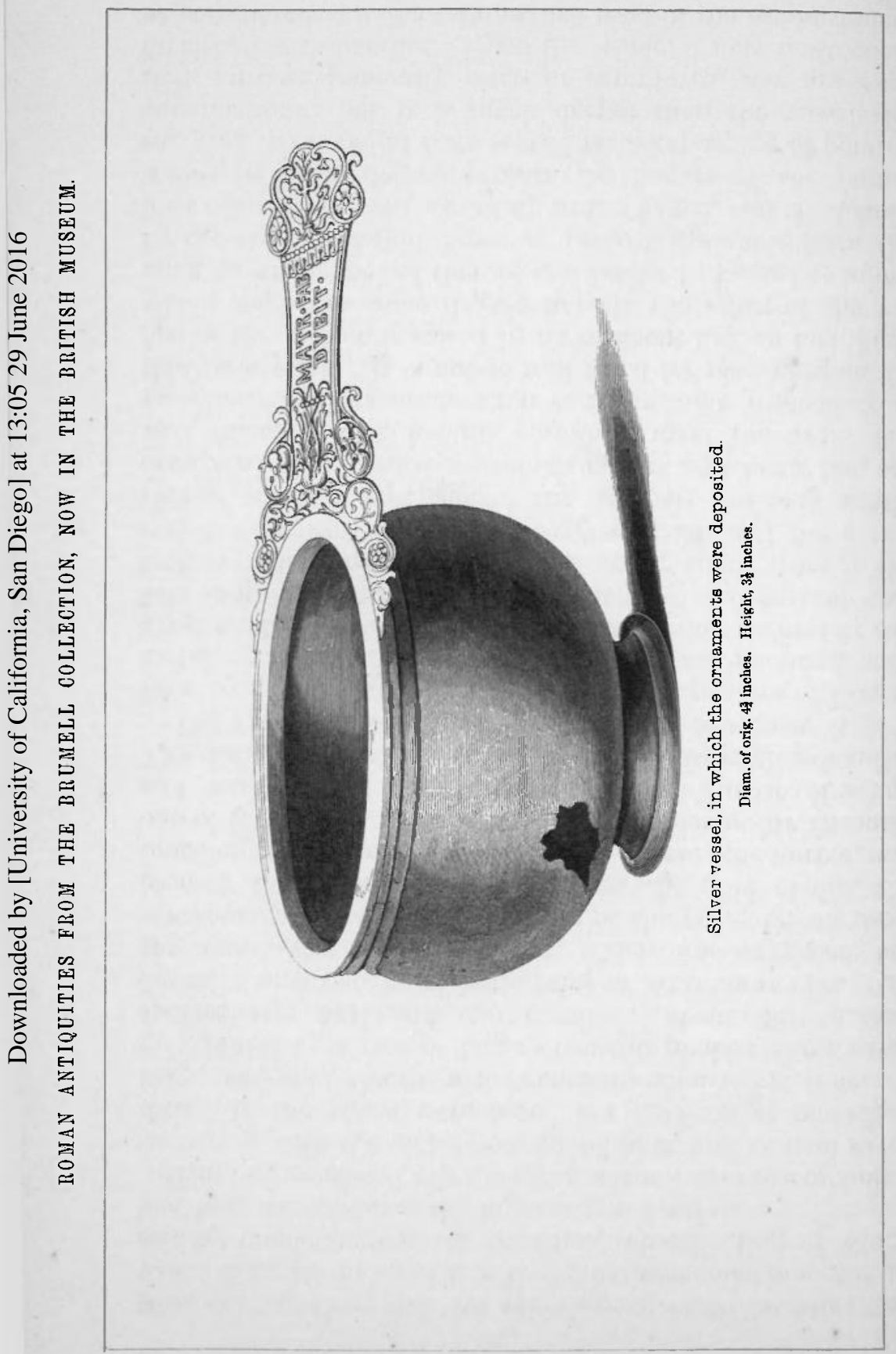


ROMAN ANTIQUITIES FROM THE BRUMELL GOLLECTION.

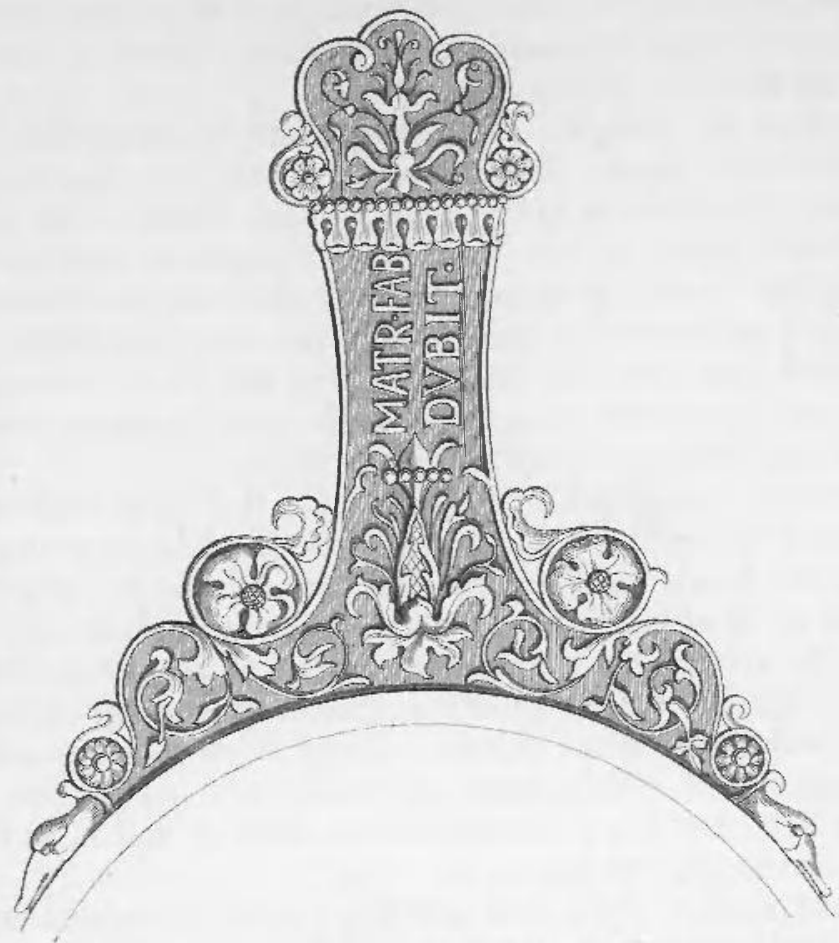

Inscribed handle of the silver vessel. Length of orig. 4 inches.
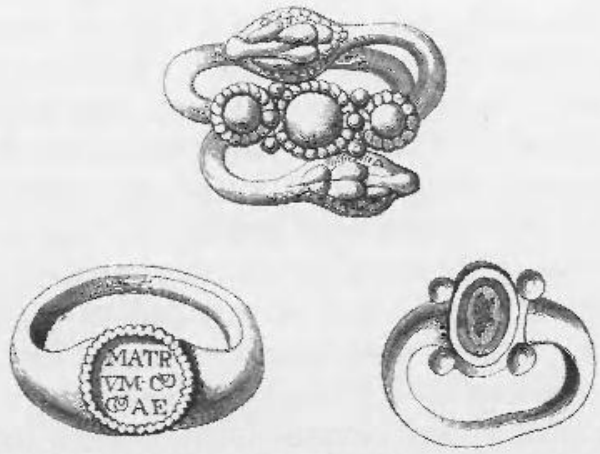

Gold rings

Orig, size. 
But who these may be, to what establishment or institution they may have been attached, or what office they may have held, little or no information is to be derived from ancient authors which will enable us to decide.

The vessel is $4 \frac{3}{4}$ inches in diameter, and $3 \frac{1}{2}$ inches high. The handle is $4 \frac{3}{4}$ inches long, broad and flat, very elegantly decorated with flowers and foliage, whose forms confer a variety and grace to its outline. It expands, where it embraces the vessel, to more than one-third of its circumference, and terminates on each side in the head of a longishbeaked bird of a duck-like form. Much of the foliage is very tastefully enriched with gold, and the letters of the inscription - MATR. FAB. DVBIT.-Consist of inlaid gold.

Of the rings contained in this vessel, the first to be noticed is of gold, weighing $8 \mathrm{dwts} .19 \mathrm{grs}$. The stud is decorated with a raised beaded border, the field within being so deeply excavated as to admit the possibility of a crystal having been inserted to cover the inscription, which reads - MATRVM COCOAE. The letters are rudely executed, not engraved,but stamped with small blunt chisels. Those of the last word, or contractions of words, were originally CVCVAE; but subsequently an o has been stamped upon each $\mathrm{v}$, and it now reads, as we see it, COCOAE.

The next ring, of gold, has nothing remarkable about it. It is set with an oval stone, on which is engraved a figure leaning upon something, but so coarsely executed that it is impossible to say whether the figure be a Cupid, a Fortune, a Faun, or a mere countryman. It weighs 8 dwts. 8 grs.

There are two other rings, also of gold, exactly resembling each other in form; each set also with an engraved stone, but so coarsely executed that the subjects cannot be ascertained. One, however, may be supposed to represent two ears of corn. The only peculiarity worthy of note is, that to each stud is attached four round knobs, assimilating in that respect to an object which will be noticed presently, and probably indicating a form fashionable at the time. These two rings weigh respectively $8 \mathrm{dwts.} 8 \mathrm{grs}$., and $5 \mathrm{dwts.} \frac{1}{2}$ grs.

The next ring is of a very elegant form, being a thick wire of gold, each end reverted, and terminating in the head of a serpent; and between these, three studs of gold, surrounded by smaller studs. These serpents' heads are peculiarly formed, having in some positions the appearance of the calyx 
and fruit of some plant, and for such they have actually been mistaken. No doubt, however, can remain of their having been intended for serpents, if they are compared with the elegant ornament of which a representation is given, and which formed part of an armlet. It was in the collection of Mr. R. P. Knight, and is supposed to have been found in England. The treatment of the serpent's head exactly corresponds with those upon the ring, and the four gold knobs attached to the stud exactly coincide with those noticed upon the two rings already described. From these coincidences it may probably be inferred that this bracelet was contemporaneous with the several objects now under consideration, and in some way connected with the worship of the Deæ Matres. There are two other objects in the collection of the British Museum which may also perhaps be connected with the same subject: these are two gold serpents, which have formed bracelets. The heads have the same peculiar treatment as those upon the ring. One is much larger than the other, and was in the collection of Mr. Knight; having, as supposed, been found with the large fragment.

The last ring found in the vessel is of silver, exactly resembling in form the serpent-ring found with it. It has unfortunately been broken, and one of the serpents' heads, with some other portions, are lost. It may be observed that all the silver objects are very much injured by time and the nature of the soil in which they were deposited.

The next objects to be noticed are two gold chains, to each of which is attached a wheel-shaped ornament, having behind it a bar, terminating at each end, beyond the circumference of the wheel, in a loop; to one of these, one end of the chain is permanently fixed; to the other, it is fastened by a long hook, as occasion might require. These chains are respectively $2 \mathrm{ft}$. 4 inches and $2 \mathrm{ft}$. 8 inches long, and to each, about eight inches from the wheel, is suspended a small crescent or lunula. A chain, with a lunula attached, and one of the wheel-like ornaments, is in the possession of Mr. Johnes, of Dolocoutha, near Llandovery, near which place they were found. ${ }^{2}$ The chain was probably broken by the workmen who discovered it, and the object of the ornaments has been mistaken; the wheel having one loop straitened

: See Archaeological Journal, vol, vii. p. 173. 


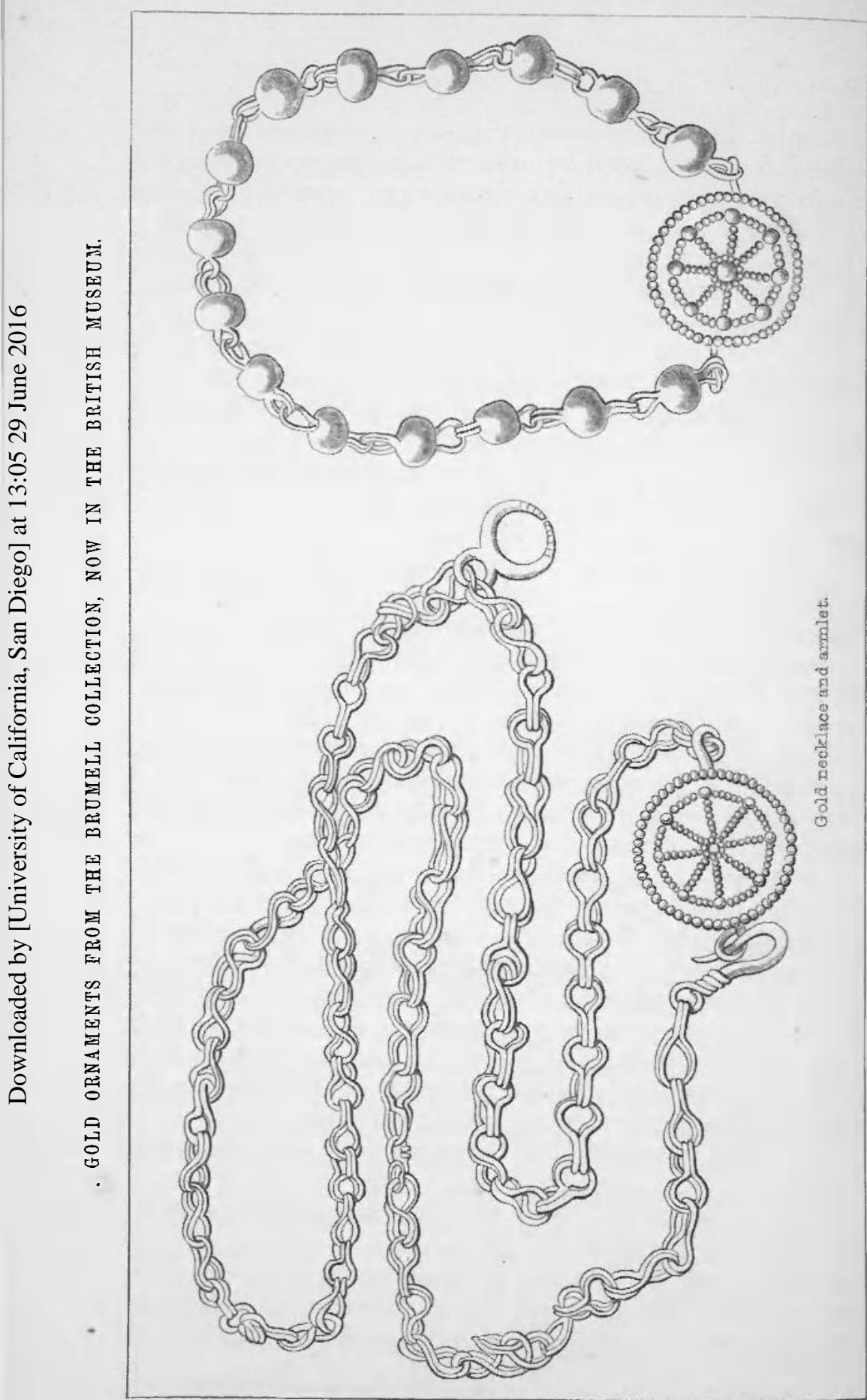


has been supposed to be a fibula ; the horns of the lunula have been more bent onwards, and converted into a loop of the chain. A chain with a wheel ornament and attached lunula, exactly resembling all these, is figured by Count Caylus, Recueil d'Antiquites, Suppl. vol. vii., Pl. xciv.; in the two following plates are chains and wheel-shaped ornaments, all found in Switzerland, and not considered in any other light by the Count than merely female ornaments of dress. With these was an armlet, terminating at each end in an ornament represented as flowers, but indisputably intended for serpents' heads; for, when analysed, all the parts correspond with those upon the heads of the serpents already mentioned. A pair of silver armlets, resembling this, were found at Castlethorpe, in the county of Bucks, about 1830. All these are coarsely executed, chiefly by the hammer and punch, not by sculpture. It is evident that the combination of the chain, the wheel-like ornament and lunula, and perhaps the serpent, was not confined to any locality, but in use in various places, and therefore probably not a mere ornament, but connected with some religious ceremony or feeling.

There is another gold chain, probably an armlet, in this collection, about seven inches long, to which a wheel-like ornament is permanently attached at both ends ; there is not any lunula attached; a hollow bead is strung upon each loop.

The two fibulæ found within the vessel are precisely similar to each other: there is not anything in their form which, had they been found unconnected with any other objects, could have led even to a conjecture as to any peculiar appropriation of them to any person or society; as, however, these were found mixed with objects connected with the worship of three united divinities, or Genii, the threefold ornament at the side may have some symbolical reference to these personages. These two objects add another, to many well-known instances, of these large fibulæ being found in pairs.

Of the three spoons, forming part of this find, two are precisely similar; the handle of one of them is wholly, or partly modern ; the form is oval, and well known to archaeologists ; the third, having a circular bowl and straight handle, is much more rare; all have a small groove round the inside of the bowl, which is not usual, and the object of which is not apparent. They are small, too small perhaps for domestic purposes, and have generally been considered to have been appropriated to sacred purposes, to draw out from the acerra, 
or usual store vessel, such small quantity of precious ointment,

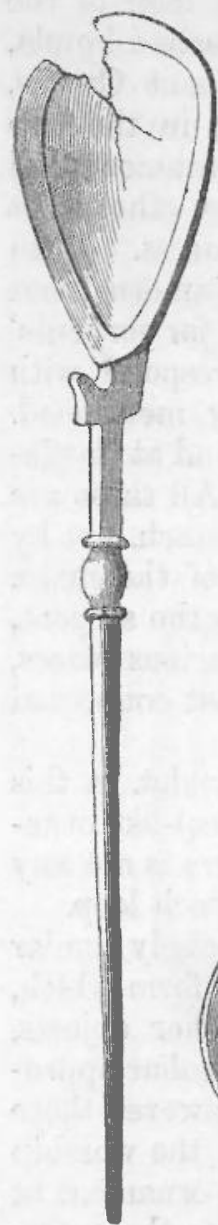
or frankincense, as might be required. (See cuts, orig. size.) The mirror is formed of a circular plate of silver, decorated on one side with concentric incised circles, and a leaf-like border surrounds the edge, which, having been only soldered on, has in a great degree been detached and lost. The mirror was found upon the saucepan, and has been supposed to be its cover. It may have been so, but it appears to be much too large for that purpose; it has all the usual form of Roman mirrors, and seems to have had some alloy mixed with the silver to adapt it for taking a polish. This has perhaps rendered it brittle, and it has been broken into several pieces; it has been repaired, not in a very graceful manner, by attaching to one side of it an ill-formed piece of silver.

One object only remains to be noticed, of little value in itself, but important as fixing the date of the objects with which it was found; it is one of the 280 denarii. It is of Antoninus Pius, struck in his second consulate, corresponding to the year 139 of our æra; and, as this was the latest coin discovered, it may reasonably be concluded that these articles were all deposited in his reign, which terminated in 161, twenty-two years after the date of the latest discovered coin, or at least before the coins of his successor could have come into general circulation in this country.

Of the Deæ Matres, with whose religious rites and ceremonies these objects appear to be connected, nothing is to be learned from ancient authors; it is only from still-existing monuments, becoming the subject of investigation by archaeo- 
logists, that any reasonable, though imperfect conclusions can be formed as to the place which they held in the mythology of our ancestors. These monuments are votive offerings, or altars, and have been found chiefly in Spain, France, Germany, and England. Where sculptured figures accompany the inscriptions, three females are represented, and they are variously, and perhaps indifferently, denominated as Matres, Matronæ, Junones, \&c. \&c. To these titles names of places are very frequently added, it may therefore be concluded that these personages were the Genii, patron saints, presiding divinities over certain localities, whether districts, towns, or places of still smaller dimensions or importance. They may also be considered as beneficent personages, more to be approached with prayers for benefits to be conferred, or with thanks for blessings already received, than with addresses deprecating expected evil, or gratitude for evils averted. They are represented holding in their hands, or on their laps, fruit, flowers, or baskets of such cornucopiæ and other symbols of fertility and abundance, implying, as usual in mythological figures, the objects offered to them in propitiation of their favours, and also those which their votaries expected to receive by their mediation. The attendants, who are represented occasionally upon these monuments, are carrying some of the various objects offered to these tutelary divinities ; and these are baskets of fruit or flowers, a bottle, evidently to contain some fluid; a pot to contain something less fluid. Now it is well known that flowers, fruit, milk, and honey, were the usual grateful offerings to rural divinities, and such therefore we may suppose to be indicated by the baskets, the jug, and the pot.

The three goddesses are generally represented seated upon a long seat, clothed in ample draperies, covering the whole person close up to the chin ; and circular fibulæ appear to have been worn in front of the neck, or upon the shoulders; but the existing sculptures, or the drawings of them, are so imperfectly finished, or are so decayed, that the exact forms cannot be satisfactorily ascertained. Small chapels are said to have been erected to their honour, or for the celebration of their rites; and a small chamber re-opened at Ellenborough, in Cumberland, in the year 1766, is supposed to have been one of these chapels. It contained three niches, in which the statues of these divinities were supposed to VOL, VIII. 
have been placed, not upon one seat, as they appear on sculptured monuments. The chapel was below the surface of the ground, in some degree corresponding with the grottos usually devoted to the service of rural divinities. (See Archæologia, vol. ii., p. 58.) For further information respecting these divinities it will be well to consult the Dissertation of the Abbe Banin (Hist. de l'Acad. Roy. des Inscriptions, Vol. vii., p. 34), and a paper by Mr. Roach Smith, in the Journal of the Archaeological Association.

The inscriptions which have been mentioned upon the objects in this collection cannot be explained with much certainty. All the known inscriptions referring to the Deæ Matres have been upon altars or commemorative tablets, and are consequently dedicatory, affording little assistance to the elucidation of these, which are perhaps the only ones which have been made known as attached to objects of ornament or utility, which may be dedicatory, or only indicating proprietorship. The inscription on the handle of the vase is MATR. FAB. DVBIT. The name of Dubitatus occurs upon two inscriptions recorded by Gruter ; it may read, therefore, MATRIBVs FaBIVs DVBITATvs, dedicated to the Deæ Matres, or to the use of their priestesses, by Fabius Dubitatus, or perhaps a female, Fabia Dubitata. Or it may be read, Matris FabiaE DVBITAT 2 , declaring it to be the property of Fabia Dubitata, a priestess of the Deæ Matres. It will be more conformable to the general nature of inscriptions to read it in the dedicatory form, and consider it as dedicated to the service of the divinities mentioned.

The inscription upon the ring, MATRVM . COCOAE, presents greater difficulties; COCOAE appears as one word, there is not any point, or mark of contraction to separate the letters into different words, or to encourage insertion. To no person, place, or office, do the indexes of Gruter or other authors apply such a name, nor any one sufficiently resembling it, to justify the conjectural emendation of a supposed error. The only course is to supply the marks of separation or contraction which, in ancient inscriptions, are frequently omitted, and endeavour to discover some plausible interpretation. It has been already stated that upon existing monuments relating to the Deæ Matres, the names of places over which these divinities presided were frequently inserted; and as these objects now under discussion were found in the north of England, it is reasonable to look out for some place 
in that part of the kingdom, whose name may possibly be indicated by the letters of the inscription; Colonia Ælia has been suggested; but besides that some of the letters would remain unexplained, the name of Newcastle is Pons Elii, not Colonia Elia. It has been conjectured that the inscription might be read, "Matrum collegii coædituæ," (To the joint housekeeper of the college of the priestesses of the Dex Matres). There are, however, strong objections to such an interpretation; there is not any authority for such a college, or such an office ; and "co " is never the abbreviation of collegium. The solution of the enigma must be left to some fortunate discovery of an explanatory inscription, or to the ingenuity of some happy CEdipus. All that appears to be satisfactorily made out is, that these objects are in some way connected with the worship of the Dex Matres; and it may be reasonably concluded that the other objects found with them were also used upon similar occasions.

It has been already stated that the divinities were approached with addresses to propitiate their influence in pro-، ducing fruitful seasons, and of such influence the moon would be considered an appropriate symbol, as beneficial to the increase of corn, cattle, and all things living. "Incrementis frugum, et pecudum, omniumque animantium commoda est ; augmentis enim ejus, detrimentisque mira quadam providentiæ arte, omne quod gignitur, alitur et crescit." 3 The prevalence of such opinions may have occasioned the introduction of lunulæ into ornaments worn by votaries of the Deæ Matres.

The moon, however, according to Aristotle, is only a lesser sun, and operates only, by a borrowed influence, in conducing to the generation and growth of all things. It would not be surprising to find the more potent luminary symbolised in the objects worn by the same votaries; and therefore those persons may be correct who have supposed the wheellike ornaments attached to these chains as emblems of the sun. If this object is more than a mere ornament, if it is a symbol also, it may perhaps be more reasonable to suppose that it symbolises what it more resembles-a wheel. The moon was considered a fit emblem of the progress of prosperity, because she was seen gradually to increase in magnitude and glory. "Quod illa sit mortalium corporum et author, et conditrix ; adeo ut nonnulla corpora sub luminis

a Clemens Roman. lib. 8. 
ejus accessu patiantur augmenta et huic decrescenti minuantur." 4 The wheel is a similar and appropriate emblem of the rise and fall of prosperity ; and though it was not so generally figured in ancient sculptures with that view, as it is in more modern times, yet the expression of Cicero Rota Fortunce shows that it was acknowledged as such.

The other object discovered, which may also have a symbolical meaning, is the serpent. The Deæ Matres were not only invoked for fertile fields and fruitful seasons, but several inscriptions prove that they were supposed to exercise a very beneficial influence over the health of individuals; the snake, therefore, the invariable companion of the Dea Salus, will be very readily admitted to be an appropriate decoration for the votaries of the Deæ Matres.

The hitherto known examples of lunulæ, wheels, or suns, and serpents, have been found under circumstances which have not afforded any elucidation of the uses to which they were applied, or the purposes for which they were made; nor were any other objects found with them which might facilitate conjecture. In this instance they have been found with objects clearly connected with the worship of the Deæ Matres, and an endeavour is made to show that they are symbols which might reasonably be supposed to appear among the paraphernalia of the priestesses and votaries of those divinities. Let it, however, be remembered that these are only conjectures formed upon exceedingly slight grounds, and thrown out, upon the present occasion, less with a view to illustrate the objects of which representations are given, than to induce Archaeologists to examine minutely and accurately, and to record at the time, faithfully and in detail, all the circumstances attending the discovery of any similar objects at which they may happily be present; and, as far as they have the power, to prevent the separation of any objects, however insignificant they may appear, which have been found together, at least till they have been thoroughly examined by persons competent to form a sound and correct judgment. Isolated objects are of little value; a collector may accumulate a number of amusing and elegant specimens, but it is only by combination, concentration, and comparison, that an entertaining collection can be converted into an instructive museum, and Archaeology erected into a science.

EDWARD HAWKINS.

4 Macrob. lib. i. in Somn. Scipionis, cap. 11. 